DOI: https://doi.org/10.47405/mjssh.v6i11.1144

\begin{tabular}{|c|c|}
\hline 4 & Malaysian Journal of Social Sciences and Humanities (MJSSH) \\
\hline $\begin{array}{l}\text { Malaysian Juoural of } \\
\text { Social ccciecces and }\end{array}$ & Volume 6, Issue 11, November 2021 \\
\hline (MJ-sSH) & e-ISSN : 2504-8562 \\
\hline & $\begin{array}{l}\text { Journal home page: } \\
\text { www.msocialsciences.com }\end{array}$ \\
\hline
\end{tabular}

\title{
The Role of Prophetic Food in The Prevention and Cure of Chronic Diseases: A Review of Literature
}

\author{
Aimi Solehah Mohamed Iqbal' ${ }^{1}$, Muhammad Tahir Jan², Betania Kartika Muflih", \\ Irwandi Jaswir ${ }^{1}$ \\ 1International Institute for Halal Research \& Training (INHART), International Islamic University Malaysia, \\ Malaysia \\ 2Department of Business Administration, Kulliyyah of Economics and Management Sciences, \\ International Islamic University Malaysia, Malaysia
}

Correspondence: Muhammad Tahir Jan (tahirjan@iium.edu.my)

\begin{abstract}
Islam is the way of life. It exists in each and every moment and action of an individual. Muhammad (PBUH) is the finest of all examples in every aspect. In Islam, halal and tayyib food is important for individual prosperity and wellbeing. This is because food intake has the potential to influence human growth in terms of akhlaq, morality, and psychology. This paper studies the significance of consuming prophetic food as a healthy diet. A few highlighted issues will be discussed, such as the increasing rate of chronic diseases that have become high causes of death, as well as unhealthy eating habits amongst Malaysians regardless of age and background. Undoubtedly, the ability of nutrition and functional food from the practice of the Prophet Muhammad (PBUH) has proven to be one of the best ways to prevent and cure most chronic diseases with the low side effects. This paper discusses how prophetic food helps in resolving global health issues and combating chronic disease. These issues are extracted from the literature by thoroughly studying published work and research. Finding shows that there is a presence of high medicinal values in prophetic food and evidence provided in The Holy Quran and Hadiths is proven scientifically through available research and citations. The paper provides valuable insights to the Prophetic food consumption among Muslim consumers and the halal industry.
\end{abstract}

Keywords: Prophetic food, chronic disease, Muhammad (PBUH), Sunnah

\section{Introduction}

Food is an essential requirement for human life. The phrase, 'a man is what he eats' portrays the utmost importance of food. It not only provides energy but builds and shapes one's behaviour and character. The function of food is not only limited to filling the stomach, but it should be taken regularly to avoid the negative effects of eating. It is critical for a human being's life and bodily nutrition to consume nutritious foods. However, due to changes in lifestyles and increasing commitments in recent times, people tend to take for granted the importance of healthy eating habits. Consuming is more than just supplying sustenance to our bodies; it also provides energy and strengthens our defence mechanisms. 
Allah (SWT) has blessed us with good health. According to Md.Sawari, Mustapha, and Ghazali (2014), we will be able to think more clearly, have more energy, and are mentally stronger when your body is healthy. Man is told in the Quran Surah Abasa verse 24, to look at his food attentively and pay attention to it, "Then let mankind look at his food". This Islamic command includes close attention to the property and impact of food on human health as well as its material and spiritual cleanliness. The use of medicinal plants as natural components with less side effects appears to be preferable to chemical treatments.

Consumption pattern behaviours among consumers is influenced by a lot of factors, including knowledge and health concerns that are now becoming new trends. Religion, according to Delener (1994), can impact customers' attitudes and behaviours, as well as their food choices and eating habits (Mullen et al., 2000). In fact, religion is one of the most significant factors in food choice in many populations (Musaiger, 1993; Dindyal \& Dindyal, 2003). Religiousness, religious education, and the halal status of the food all impact Muslim customers' purchase and consumption habits. The undesirable side effects of contemporary medicine and pharmaceutical goods have diminished people's confidence. Also, there is uncertainty of Halal status in the majority of halal pharmaceutical products in the market that has become an issue for halal industries. All of these paramount issues might be one of the contributing factors towards increasing demand for Prophetic food products.

Lately, Prophetic foods are gaining popularity among Malaysia's Muslim community. This is demonstrated by the large number of Prophetic food products made by local Muslim businesses such as Hiraq Marketing, Saffron Integrated Marketing, Qaseh Gold, Natural herbs, and many more. Despite the growing demand, there have been little research attempted to evaluate Malaysians' perceptions and acceptance of Prophetic foods. In addition, the percentage of Malaysians practicing prophetic foods as their daily consumption routine is not encouraging (AIMa, 1980; Ali M, 2011). Despite several pieces of data highlighting the advantages and efficacy of such a diet, only a small percentage of Muslims trust and adhere to it. Apart from that, a few studies reported that the number of chronic disease patients is increasing in Malaysia due to unhealthy eating patterns and high-paced lifestyle.

\section{Literature Review}

\section{Issues}

Despite extensive usage of health-related products, the prevalence of noncommunicable diseases, especially heart disease and cancer, is increasing. According to Malaysian Department of Statistics data for 2020, ischemic heart disease is the leading cause of death in Malaysia, representing for 15.0 percent of the 109,164 medically certified fatalities in 2019. The next most frequent conditions were pneumonia (12.2 percent), cerebrovascular diseases ( 8.0 percent), and malignant tumour of the trachea, bronchus, and lung (2.4 percent). Diabetes affects approximately 422 million people worldwide, the vast majority of whom live in low- and middle-income countries, and it is directly responsible for 1.6 million deaths per year.

Unhealthy eating habits are a significant contributor to the rise of chronic illnesses. Meal skipping, snacking, eating away from home, fast food consumption regularly, snack consumption, and unusual dietary patterns such as adopting a vegetarian diet, specialised weight loss programmes, and an overall reduction of food intake are common eating patterns among teenagers (Savige et al., 2007). Furthermore, the population does not completely comprehend the habit of consuming Prophetic foods, which are incredibly healthy (Rani et al., 2017).

\section{Prophetic foods mentioned in the Quran and Hadiths and the benefit of consumption.}

Allah (SWT) bestowed Prophet Muhammad (PBUH) with the status of Uswah Hasanah (role model). Allah SWT declared: "In God's Messenger you have a good model." (Surah Al-Ahzab 33:21). 
This verse definitely emphasises that the Prophet Muhammad (PBUH) serves as a role model for Muslims. Because the Prophet Muhammad (PBUH) was sent as an example to mankind, his health and personal hygiene practices serve as a guidance for his followers. A Sunnah diet is one of the Prophet Muhammad's (PBUH) numerous teachings that substantially enhances human health and has a beneficial influence on an individual's whole existence.

Both the Quran and Sunnah advocate nutrient-dense foods and forbid the intake of substances that have been shown to be toxic or whose drawbacks outweigh their benefits. Prophetic Medicine, which encompasses herbal knowledge, cleanliness, and dietary habits, was created during the time of the Prophet Muhammad (PBUH). It contains medicine recipes that the Prophet (PBUH) was cured with or that he commanded others to be cured with. Additionally, it also contains advice that are applicable to human health in real-life situations, such as his daily intake pattern and methods for treating and avoiding illnesses.

Prophetic foods, also known as Sunnah foods, are a category of foods that have been commended in the Quran and Hadith and have been shown to have several health advantages. It is also recommended by the Prophet Muhammad for Muslims to have a better and healthier lifestyle (Hashman, 2011). In his book, Zad Al Ma'ad Fe Haday Khair Al Abad, Ibn Al Qayyim, said: "The medication of the Messenger (PBUH), is not identical to the medicine of physicians." While others' medicine is inductive, assumptive, and experimental, the medicine of the Prophet (PBUH) is definite, categorical, and godly medicine, given by the Revelation, prophethood niche, and sagacity."

There are several verses in the Quran that touched on nutrition, which should be a reference to humankind: "O mankind! Eat of what is lawful and good on earth" (2:168). "Eat of the good things we have provided for your sustenance, but commit no excess therein, lest my wrath should justly descend on you, and those whom descends my wrath do perish indeed" (20:81).

\section{Prophetic foods as combating agent of chronic diseases}

Chronic illnesses such as cardiovascular disease are the primary causes of mortality in the United States of America (USA), followed by cancer in the majority of industrial countries. Liu (2013) reports in his study that strokes, Alzheimer disease, cataracts and some dysfunctions of the human body in alignment with the increment of age can be reduced through daily consumption of fruits and vegetables. Therefore, this could be positively related to the 'signs' from Allah SWT in which He revealed that consuming fruits is a healthy and natural preventative measure against severe diseases as well as various illnesses.

A vast number of scientific studies have confirmed these diets, pointing to several advantages, particularly in the prevention of cancer and cardiovascular disease (Tantamango-Bartley et al., 2013). A large body of evidence suggests that prophetic food has antihypertensive properties (Teledo et al., 2013) and metabolic syndrome (Espasito et al., 2007). Prophetic food is a healthy eating habit that has been linked to a lower risk of neurodegenerative illnesses. One of the most widely accepted ideas is that people who follow a Mediterranean diet, which includes the foods used by the Prophet, have a better overall health condition and a lower risk of major chronic illnesses. This is due to the high amount of beneficial substances such as antioxidants, which are abundant in green vegetables, fruits, and olive oil monounsaturated or polyunsaturated fatty acids.

\section{Honey}

Honey is a natural food and a complex mixture of sugar liquid with a sticky texture, the major ingredients of which are fructose and glucose. It has been found to have unique antioxidants and antibacterial activities (Erejuwa et al., 2012; Israili, 2014). Laila et al. (2012) proposed in contemporary medicine that pure honey in modest dosages might be advised as a source of carbohydrates and even as a sweetening agent for diabetic patients. Honey intake increased serum 
antioxidant capacity, according to Omotayo et al. (2010). Because oxidative stress has been related to both the development and effects of diabetes, the particular antioxidant efficacy of honey compounds may provide an organ-protective effect, perhaps delaying diabetes progression and reducing severity.

Figure 1: Prophetic food in Clinical studies as remedy and concoction nutrition.

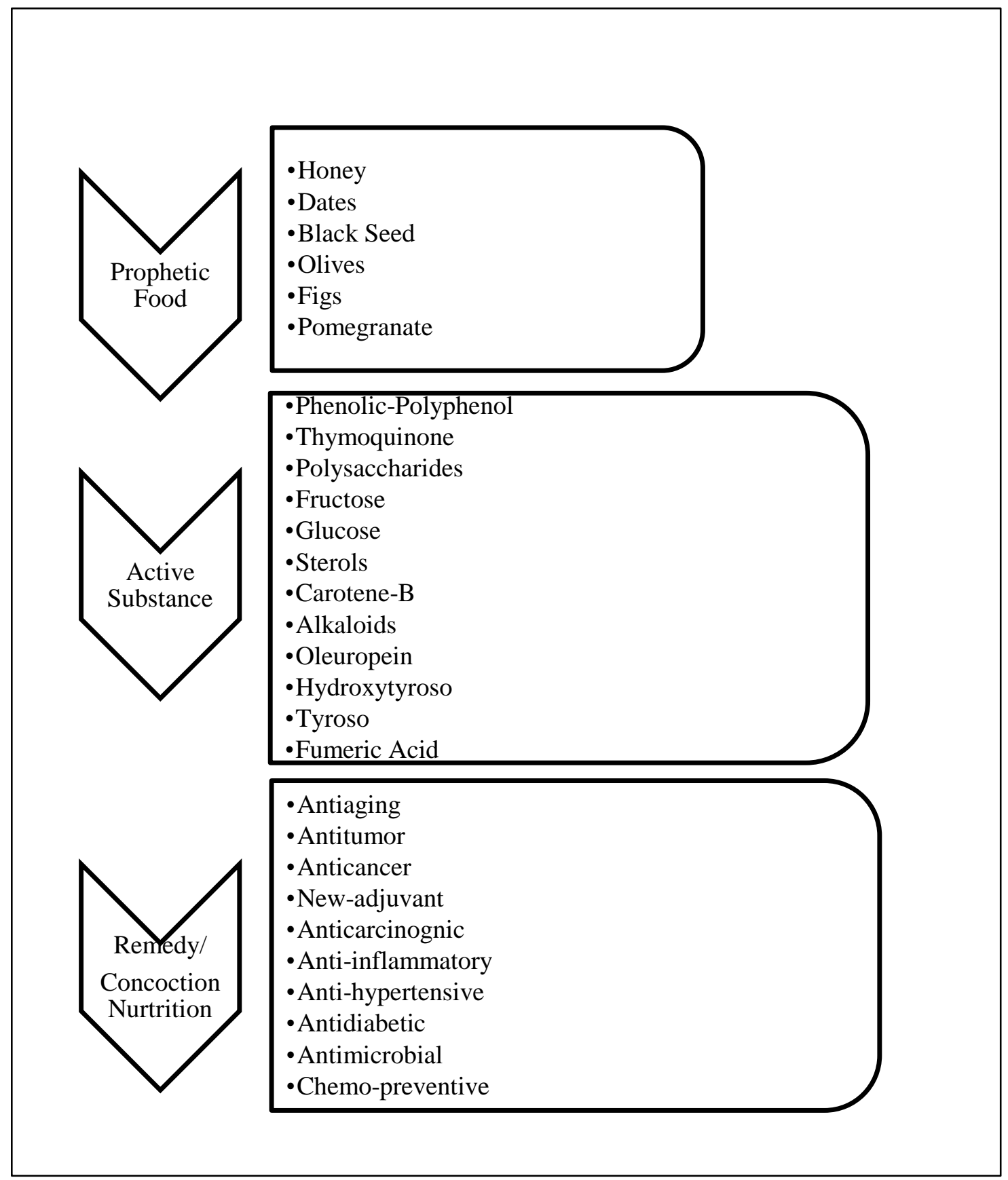

It is scientifically tested that honey could help in healing and dressing wounds, burns and ulcers. According to Yanovski (2003), honey includes a combination of sucrose, fructose, and glucose that aids in the production of energy in the human body. On top of that, glucose and fructose in pure honey encourages the absorption of water from the intestine without increasing the absorption of sodium to patients suffering from diarrhea. Honey is efficient in killing germs, according to research done by two different departments at Colorado Agricultural College and the University of Ottawa's Enzymology Department. Throughout the experiment they found out that pure honey can kill germs that cause various diseases within 48 hours such as germs that can cause typhus, typhoid and dysentery. 
Traditional medicine has been used to cure illnesses since the dawn of civilization. Apis mellifera (A. mellifera) honey is one of the world's oldest traditional medicines, and it's used to cure a variety of human diseases (Manisha \& Shyamapada, 2011). On top of that, some research has found that the antibiotics in honey help in the healing of infected wounds and chronic skin ulcers. Honey's healing properties stem from its antibacterial activity, ability to keep wounds moist, and high viscosity, which helps to form a protective barrier against infection. Its immunomodulatory properties are important in wound healing (Manisha \& Shyamapada, 2011).

According to a recent study on the effects of honey on stomach secretions such as acids and enzymes by Saad et al. (2017), honey helps to lower the secretion of hydrochloric acid to normal levels, which aids in the healing process of stomach and duodenal ulcers. Another benefit of honey consumption is that it helps to repair damaged intestinal mucosa and works as an anti-inflammatory. In a variety of cancer cell lines, honey has been demonstrated to cause cell cycle arrest. Honey treatments also inhibited cell proliferation in bladder cancer cells by triggering cell cycle arrest (Tarek et al., 2003)

In the Holy Quran, Allah the almighty says: "Then eat from all the fruits and follow the ways of your Lord laid down [for you]." There emerges from their bellies a drink, varying in colors, in which there is healing for people. Indeed, in that is a sign for a people who give thought" (Surah Al-Nahl,16:69).

Honey is also referenced in Saheeh Al-Bukhaari in a narration by "Aa'ishah, may Allah be pleased with her, who says: "The Messenger of Allah, used to love sweet edible things and honey." The Prophet (PBUH) also attributed many healing powers to honey, for example when he recommended it to a man suffering from stomach upset. A man came to the Prophet (PBUH) and said, "My brother has some abdominal trouble." The Prophet said to him "Let him drink honey." The man came for the second time and the Prophet said to him, "Let him drink honey." He came for the third time and the Prophet said, "Let him drink honey." He returned and said, "I have done that." The Prophet then said, "Allah has said the truth, but your brother's abdomen has told a lie. Let him drink honey." So, he made him drink honey and he was cured (Al-Bukhari).

\section{Dates}

Dates are among the fruits to be grown and have long been a staple of the Middle Eastern diet. They are a "drupe" fruit that grows on Arecaceae palm trees in the genus Phoenix, and are scientifically known as Phoenix dactylifera. Dates are regarded as the richest food in glucose. This is the reason they are an ideal food for the body, because they contain a high level of sugar which varies between 75 and 90 percent, of which glucose forms 55 percent and fructose forms 45 percent. Furthermore, AlFarisi and Lee (2008) revealed that dates are high in phytochemicals such as anthocyanins, carotenoids, flavonoids, phenolics, procyanidins, and sterols, all of which contribute to their health benefits.

Furthermore, dates are the greatest type of fruit since they are easy to ingest and their high carbohydrate content is quickly absorbed by the body. Dates are also high in minerals including calcium, manganese, copper, and magnesium. In the human body, manganese serves as a cofactor for the antioxidant enzyme superoxide dismutase. Copper is required for the production of red blood cells. Furthermore, magnesium is required for human bone development.

This fruit also contains modest amounts of the B-complex vitamins, as well as vitamin K. Pyridoxine (vitamin B-6), niacin (vitamin B-3), pantothenic acid (vitamin B-5), and riboflavin (vitamin B-2) are all present in sufficient amounts. As cofactors, these vitamins help the body digest carbohydrates, protein, and fats. Vitamin $\mathrm{K}$ is required for several coagulant factors in the blood as well as bone metabolism.

Scientifically proven by Omar and John (2005) is the presence of glucans in dates helping to slow down antitumor activity. For example, the presence of certain b-D-glucans in dates substantially influences their anticancer, antineoplastic, and apoptosis-inducing activities, according to earlier studies by Omar et al. (2004). Although there is minimal evidence about dates as a possible anticancer 
drug, research show that Phonix dactylifera has an indirect antitumor effect through modulating the immune system. Further, it aids in the treatment of diabetes and the prevention of endocrine-related diseases including osteoporosis, cardiovascular disease, menopausal symptoms, and breast and prostate cancer. Dates contain the second greatest amounts of these phytoestrogens of any fruit, according to research. 2016 (Dr. Stephen Atkin). Dates as an example of good food is also highlighted a few times in Surah An-Nahl: "He causes to grow for you thereby the crops, olives, palm trees, grapevines, and from all the fruits. Indeed in that is a sign for a people who give thought. (An-Nahl) 16:11).

In addition, The Prophet (PBUH) said, "There is a tree among the trees which is similar to a Muslim (in goodness), and that is the date palm tree." (Al-Bukhaari).

The blood glucose level in our bodies begins to decline many hours after a meal, leading to a decrease in insulin production and an increase in glucagon secretion, according to Biochemistry 5th Edition. In response to a low blood sugar level, the pancreas secretes glucagon when fasting. The liver is glucagon's primary target organ. At this stage, all of our body's tissues rely on the oxidation of fatty acids and the oxidation of glucose produced in the liver from amino acids and glycerol to provide energy. So the idea of breaking fast with dates stated by the Prophet (PBUH) is the perfect practice that should be followed by Muslims. In the Hadith by Al-Tirmidhi, he said, "When one of you breaks the fast, let him do so with dates for they are blessing and if he cannot find dated then with water, for it is a purification"

It is scientifically proven that when we break fast with dates the immediate supply of glucose in the hepatic portal vein will rise quickly as soon as it is absorbed. This instant absorption process will stop the oxidation of fatty acids thus preventing the formation of harmful ketones and dispelling symptoms of overall weakness and slight disorder in a large amount of fats. The protein level in the body also will be preserved when the destruction of amino acids stops releasing in the liver.

\section{Black Seeds}

One of the most well-known names for the black seed is Habbat Al-Barakah, or the seed of blessing is called Shuneiz in Persian. The plant from which the black seed originates, Nigella sativa, belongs to the plant family Ranunculaceae of which more than twenty species are found worldwide. For ages, the Nigella sativa seed has been an essential nutritional flavouring agent and natural treatment for a variety of illnesses in old medical systems, such as Ayurvedic medicine. Medicines from Unani, Ayurveda, Chinese, and Arabic traditions.

Nigella sativa, also known as black seed, is an ethnomedicinal plant used to treat bronchitis, asthma, eczema, fever, digestive disturbances, hypertension, influenza, and as a diuretic and anti-inflammatory agent in Northern Africa, India, and the Middle East (Amin \& Muneera, 2015).There is some scientific evidence that the black seeds have anticancer (Randhawa \& Alghamdi, 2011), antidiabetic (El-Ameen, et al., 2015), antidiuretic, anti-inflammatory (Ali \& Gerald, 2003), and antimicrobial properties (Mehta, Vikas, \& Meenal, 2009). Polyphenols, alkaloids, and sap are some of the bioactive components found in the plant. In numerous liver injury models, Al-Ghamdi (2003) revealed that Nigella Sativa oil showed hepatoprotective effects.

Narrated by Khalid bin Sa'd: "We went out and Ghalib bin Abjar was accompanying us. He fell ill on the way and when we arrived at Medina he was still sick. Ibn Abi 'Atiq came to visit him and said to us, "Treat him with black cumin. Take five or seven seeds and crush them (mix the powder with oil) and drop the resulting mixture into both nostrils, for 'Aisha (RA) has narrated to me that she heard the Prophet saying, 'This black cumin is healing for all diseases except As-Sam.' 'Aisha said, 'What is As-Sam?' He said, 'Death.' ” (Bukhari) 


\section{Olives}

The olive tree is an evergreen tree that is native to the Mediterranean, Asia, and Africa's coastlines and belongs to the Oleaceae family. Olive tree leaves have traditionally been used to treat fevers and malaria. The oil, often known as virgin olive oil or extra virgin olive oil, is primarily responsible for the therapeutic use of olives as a functional food. A recent research in Crete found that, despite the fact that 90 percent of Cretans consume 60-70 pounds of oil per year on average, the risk of cardiovascular disease is relatively low when compared to other nations. Olive oil has antihypertensive, antithrombotic, antioxidant, anti-inflammatory, and anti-carcinogenic properties due to the presence of particular components (Buckland \& Gonzalez, 2015).

Olive oil's high antioxidant capabilities, as a result of its particular fatty acid makeup, as well as the inclusion of different nutrients, such as vitamin $\mathrm{E}$ and polyphenols, have been described as a possible cancer-fighting benefit (Pelucchi et al., 2011). Olive oil, the most commonly used seasoning fat and the main source of monounsaturated fatty acids in Mediterranean cuisine, has also been reported to be a favourable indicator of a variety of common cancers (Pelucchi et al., 2011), with the most promising results for breast, digestive tract cancers, liver cancer, and lung cancer (Kelly et al.2011; Cardeno, Sá et al., 2013).

Due to the obvious high amount of monounsaturated fatty acids, which can protect lipoproteins and cellular membranes from oxidative damage and inflammation, olives are considered to lower the risk of cancer formation and are cardioprotective (Lucas et al., 2011; Claudia et al., 2016). According to Claudia et al. (2016), the primary nutraceutical components found in extra-virgin olive oil include mono-unsaturated fatty acids and various phenolic compounds such as oleocanthal, oleuropein, hydroxytyrosol, and tyrosol. These molecules are thought to have the ability to control aging-related processes.

The olive is mentioned several times in the Holy Quran, for example in the Surah Al-Mu'minun verse 20, "And a tree (olive) that springs forth from Mount Sinai, that grows oil, and (it is a) relish for the eaters"

Olives are also mentioned by the Prophet Muhammad (PBUH) in a few Hadiths, advising us to: "Use olive oil as a food and ointment for it comes from a blessed tree" (At-Tirmdhi).

\section{Figs}

The fig tree is known with the scientific name of Ficus Carica L. The common fig tree is a longstanding crop throughout the Mediterranean region, as well as western and eastern Asia. The fig tree has evolved a vast root system to get water from the soil many metres distant from the trunk, allowing it to thrive in dry, desert areas with hot summers. Thermophilic trees, such as the fig tree, may be beneficial in adapting to the effects of climate change and global warming by allowing them to thrive in hot, dry environments when other species may not (Sugiura et al., 2007). According to Paknahad and Saharafi (2015), dried figs include 29\% water, 50\% sugar, $4 \%$ protein, 5.5 percent nitrogen, $2 \%$ fatty material, and a compound known as Psoralen.

Fig can be found among plants mentioned in the Quran and the Islamic teachings in the form of numerous hadiths. In Surah At-Tin, Allah point out the medicinal benefits of fig so that in verses 1 through 3 of this surah, figs and olives have been sworn by; "By the Figs and the Olives. By Mount Sinai. By this city of security" (At-Tin,95: 1-3).

Figs are highly used as prevention to malignant and inflammatory diseases. Most significantly, figs offer a variety of ethnomedicinal applications, including the treatment of gastrointestinal (colic, indigestion, lack of appetite, and diarrhoea), respiratory (sore throats, coughs, and bronchial difficulties), cardiovascular, and anti-inflammatory diseases (Ephraim et al., 2008).On top of that figs are also high in carbohydrates, dietary fibre, minerals, organic acids, and amino acids, while being low in fat and cholesterol (Slatnar et al., 2011; Seong \& Lachance, 2001). In a more recent investigation, 
fig fruit, leaves, and latex extracts were found to be effective cytotoxic agents against cervical cancer (Khodarahmi et al., 2011).

\section{Limitations and future study}

The implications of this study are mitigated by a number of limitations that must be addressed in future research. This study concentrated solely on the facts of scientifically established benefits of ingesting Prophetic food for the prevention and cure of chronic illnesses. There more and bigger scope of study involve the implication and aftereffect of consuming Prophetic food suggested by the Prophet Muhammad (PBUH). This study only listed several types of Prophetic food somehow there are a few more natural foods mentioned in the Quran and consumed by the Prophet Muhammad (PBUH). Conversely, there other important aspect that related to the consumptions of Prophetic food which are the ethics, ways and prescriptions of consuming the therapeutic properties of the fruits and drinks for human being in a way of preventing and curing chronic disease. Further investigation is suggested for better understanding of the consumer behavioural and perceptions in regards to the consumptions of the Prophetic food.

\section{Conclusion}

Prophet Muhammad (PBUH) is the finest of all examples in every aspect. Recorded in the sahih hadith, since the $6^{\text {th }}$ century, the Prophet Muhammad (PBUH) His dietary routine, his manners and etiquette is explained in a detailed and precise way for Muslims to follow. At this time when science was not available to prove the benefits of the prophetic diet, it was not considered as having medicinal value. In this present century when science has advanced and chronic disease has increased in numbers, a great number of scientific research has been done on prophetic food. The advance in science has given light to the benefits of food consumed by the Prophet Muhammad (PBUH).

Trust in modern medicine to cure chronic diseases is deteriorating. Most of the treatments are pain killers, thus not having an answer in the long run. For a Muslim, halal products can be a sensitive issue and the usage of animal substances in the pharmaceutical industry seem to hamper trust in modern medicine even more. When in doubt over the halal status or syubhah, one will opt to avoid usage of modern medicine. Lately, the trust in prophetic food, due to its contents and medicinal value has led to a growth to the halal industry. Trillions of dollars are being invested in this research to further understand this area.

\section{References}

Abu Dawud. (n.d.). Sunan Abu Dawud (Vol. 3). Beirut: Hadith No: 3836. Dar Kutub al-Ilmiyyah. AIMa , T. (1980). Sunan al-Tirmizi. Dar al-Fikr, Beirut.

Al-Farisi, M., \& Lee, C. (2008, October). Nutritional and Functional Properties of Dates: A Review. Critical Revies in Food Science and Nutrition, 877-887.

Al-Ghamdi, M. S. (2003). Protective Effect of Nigella sativa Seeds Against Carbon Tetrachlorideinduced Liver Damage. The American Journal of Chinese Medicine, 31(5), 721-728.

Al-Ghazali. (n.d.). Ihya Ulum al-Din. Dar Ibn Haytham. Cairo.

Ali, B., \& Gerald, B. (2003, April). Pharmacological and toxicological properties of Nigella sativa. Phytotherapy Research, 17(4).

Ali, M. (2011). Holy Quran: Ahmadiyya Anjuman Ishaat Islam Lahore USA.

Amin, F., \& Muneera, W. (2015, Sept). Immunomodulatory and anti-inflammatory action of Nigella sativa and thymoquinone: A comprehensive review. International Immunopharmacology, 28(1), 295-304. 
Buckland, G., \& Gonzalez, C. (2015, April). The role of olive oil in disease prevention: a focus on the recent epidemiological evidence from cohort studies and dietary intervention trials.

Cárdeno, A., Sánchez-Hidalgo, M., \& Alarcón-de-la-Lastra, C. (2013). An Up-date of Olive Oil Phenols in Inflammation and Cancer: Molecular Mechanisms and Clinical Implications. Current Medicinal Chemistry, 20(37).

Chia, J., Lee, G., Wen, L., \& Ching, C. (2010, Jan). Anti-inflammatory effects of Punica granatum Linne invitro and in vivo. Food Chemistry, 118(2), 315-322.

Claudia, V., Giulia, A., Giuseppina, C., Giuseppina, C., Sonya, V., \& Calogero , C. (2016, April). Nutraceutical Properties of Extra-Virgin Olive Oil: A Natural Remedy for Age-Related Disease? Rejuvenation Research, 17(2).

Delener, N. (1994). Religious contrasts in consumer decision behaviour patterns: their dimensions and marketing implications. European Journal of Marketing, 36-53.

Dindyal, S., \& Dindyal, S. (2003). How personal factors, including culture and ethnicity, affect the choices and selection of food we make. Internet Journal of Third World Medicine, 27-33.

Department of Statistic Malaysia. (2018). Statistics on Causes of Death. Malaysia.

El-Ameen, N., Taha, M., Abdelwahab, S., Khalid, A., Elfatih, F., \& Kamel, M. (2015). Anti-diabetic properties of thymoquinone is unassociated with glycogen phosphorylase inhibition. 7 .

Ephraim, P., Helena, M., Alison, D., \& Robert, A. (2008). Ficus spp. (fig): Ethnobotany and potential as anticancer and anti-inflammatory agents. 195-213.

Erejuwa, O., Sulaiman, S., \& Ab Wahab, M. (2012). Honey: a novel antioxidant. Universiti Sains Malaysia, Department of Pharmacology, School of Medical Sciences. MDPI.

Espasito, K., Ciotola, M., \& Giugliano. (2007, Oct). Mediterranean diet and the metabolic syndrome. Mol Nutr Food Res, 51(10).

Hashman, A. (2011). Mengapa Rasullullah tidak pernah sakit. Selangor: PTS Millennia.

Israili, Z. (2014). Antimicrobial properties of honey. 21, 304-323.

Kelly, A., Gleice, d., Leonardo, C.-R., Janaina , F., Christina, M., \& Cerli , R. (2011, December). Oleanolic Acid Initiates Apoptosis in Non-Small Cell Lung Cancer Cell Lines and Reduces Metastasis of a B16F10 Melanoma Model In Vivo.

Khan, N., Afaq, F., \& Mukhta, H. (2007). Cancer chemoprevention through dietary antioxidants: progress and promise. Antioxid Redox Signal. Cancer Res, 67, 475-510.

Khodarahmi, G., Ghasemi, N., Hassanzadeh, F., \& Safaie, M. (2011). Cytotoxics effects of differen extract and latex of Ficus carica o HeLacell Line. 10(2), 273.

Krueger, R. (1998). Date palm germplasm: overview and utilization in the USA. Proceedings of the First International Conference on Date Palms (pp. 2-37). Al Ain: UAE University.

Laila, R., Parveen, F., Khan, M., Rahman, F., Ara, F., \& Saha, R. (2012). Effect of natural honey on blood glucose level of alloxan induced diabetic rats (Vol. 20). J Dhaka Med Coll.

Lucas, L., Russell, A., \& Keast, R. (2011). Molecular Mechanisms of Inflammation. AntiInflammatory Benefits of Virgin Olive Oil and the Phenolic Compound Oleocanthal. Current Pharmaceutical Design, 17(8), 754-768.

Lusby, P., Coombes, A., \& Wilkinson, J. (2005). Bactericidal activity of different honeys against pathogenic bacteria. Arch Med Res, 36, 464-467.

Manisha, D., \& Shyamapada , M. (2011, April). Honey: its medicinal property and antibacterial activity. Asian Pacific Journal of Tropical Biomedicine, 1(2).

Md.Sawari, S., Mustapha, N., \& Ghazali, M. (2014). The Impact of Halal Food on Physical And Mental Health. International Seminar on Islamic Law, Economic, Education and Science Issues, Dewan Senat, Universiti Teknologi Malaysia.

Mehta, B., Vikas, P., \& Meenal, G. (2009). New principles from seeds of Nigella sativa. Formerly Natural Product Letters, 23(2), 138-148.

Muhammad Iia, B. (2001). Sahih al-Bukhari. Dar Tawq al-Najat, Beirut.

Mullen, K., Williams, R., \& Hunt. (2000). Irish descent, religion and food consumption in the west of Scotland: Appetite. 47-54.

Musaiger, A. (1993). Socio-cultural and economic factors affecting food consumption patterns in the Arab countries. The Journal of the Royal Society for the Promotion of Health, 113(2), 68-74.

Norazlina, A. A. (2017). Halal Pharmaceutical in Malaysia: The need for legal and administrative framework. International Islamic Univeristy Malaysia, Kuliyah of Law. 
Omar, I., Faraj , Z., Adel, K., Mansur , F., \& Mohamed , E. (2004, Aug). Antitumor Activity of $\beta$-DGlucan from Libyan Dates. Journal of Medicinal Food, 7(2).

Omar, I., \& John, F. (2005, March). The anti-cancer activity of polysaccharide prepared from Libyan dates (Phoenix dactylifera L.). 59(4), 531-535.

Omotayo, E., Gurtu, S., Sulaiman, S., Wahab, M., Sirajudeen, K., \& Salleh, M. (2010). Hypoglycemic and antioxidant effects of honey supplementation in streptozotocin-induced diabetic rats. 80, 74.

Paknahad, A., \& Saharafi, M. (2015). Benefits of fig as viewed by Islam and modern medicine. International Journal of Agriculture and Crop Science, 8, 682-685.

Pelucchi, C., Bosetti, C., Negri, E., Lipworth, L., \& La Vecchia, C. (2011). Olive oil and cancer risk: an update of epidemiological findings through. Curr Pharm Des, 805-812.

Randhawa, M., \& Alghamdi, M. (2011). Anticancer Activity of Nigella sativa (Black Seed) - A Review. The American Journal of Chinese Medicine, 39(6).

Rani, M., Umar, N., Rahman, Z., Abdullah, M., \& Salleh, N. (2017). Knowledge of Prophetic Food Consumption in Malaysia: Halal, Health Benefits and Practices. Contemporary Issues and Development in the Global Halal Industry.

Saad, B. A., Aymn, T. A., Rashad, R. A.-H., Nagla, A. E.-S., Umama, A. A.-d., Soad, S. A., . . . Steven, M. H. (2017, Jan). Manuka Honey Exerts Antioxidant and Anti-Inflammatory Activities That Promote Healing of Acetic Acid-Induced Gastric Ulcer in Rats.

Savige, G., MacFarlane, A., Ball, K., Worsley, A., \& Crawford, D. (2007). Snacking behaviours of adolescents and their association with skipping meals. International Journal of Behavioral Nutrition and Physical Activity.

Seong, W., \& Lachance, P. (2001). Phytosterolsand fatty acids in fig- fruits and tree components. $66(2), 278-281$.

Sheikh, Y. B. (2016, August). The role of prophetic medicine in the management of diabetes mellitus: A review of literature. Journal of Taibah University Medical Science, 11(4), 339-352.

Slatnar, A., Klancar, U., Stampar, F., \& Veberic, R. (2011). Effect of dying of figs on the content of sugars, organicacids, ad phenolic compound. 59(21), 195-213.

Sugiura, T., Kuroda, H., \& Sugiura, H. (2007). Influence of the current state of global warming on fruit tree growth in Japan. Hort.Res, 257-263.

Tantamango-Bartley, Y., Jaceldo-Siegl, K., Fan, J., \& Fraser, G. (2013, Feb). Vegetarian Diets and the Incidence of Cancer in a Low-risk Population.

Tarek, S., NAOTO, M., MIZUKI, O., KAZUNORI, H., KOJI, K., TORU, S., \& HIDEYUKI, A. (2003, March). Antineoplastic activity of honey in an experimental bladder cancer implantation model: In vivo and in vitro studies.

Toledo, E., Estruch, R., Buil, C., \& Corella D. (2013). Effect of the Mediterranean diet on blood pressure in the PREDIMED trial: results from a randomized controlled trial. 19(11).

Tonks, A., Cooper, R., Price, A., Molan, P., \& Jones, K. (2001). Stimulation of TNF-alpha release in monocytes by honey. 14, 240-242.

Welten, D., Kemper, H., Post, G., Van Staveren, W., \& Twisk, J. (1997). Longitudinal development and tracking of calcium and dairy intake from teenager to adult. 51, 612-620.

Yanovski, S. (2003). Sugar and Fat: Cravings and Aversions. The Journal of Nutrition, 133, 835-837. 